\title{
IV. On the power of horses
}

\section{B. Bevan Esq.}

To cite this article: B. Bevan Esq. (1830) IV. On the power of horses, Philosophical Magazine Series 2, 8:43, 22-23, DOI: 10.1080/14786443008675353

To link to this article: http://dx.doi.org/10.1080/14786443008675353

曲 Published online: 13 Jul 2009.

Submit your article to this journal

Џ Article views: 2

Q View related articles $₫$ 


\section{[ 22 ]}

IV. On the Porver of Horses. By B. Bevan, Esq.

To the Editors of the Philosophical Magazine and Annals.

Gentlemen,

TO determine the average power of horses under different kinds of labour, has been a subject deemed worthy of the inquiries of many of the first class of scientific writers. It is one of those points which can be determined only by experiment. The power to be maintained depends upon the velocity; - and various formulæ are given by writers on this subject. Thus, Professor Leslie gives $(15-v)^{2}=$ pounds avoirdupoise for the power of traction of a strong horse, and $(12-v)^{2}=$ pounds traction of the ordinary horse, $v=$ velocity in miles per hour.

In the period from 1803 to 1809 , I had the opportunity of ascertaining correctly the mean force exerted by good horses in drawing the plough ; having had the superintendence of the experiments on that head at the various ploughing matches, both at Woburn and Ashridge, under the patronage of the Duke of Bedford and the Earl of Bridgewater. I find among my memoranda the result of eight ploughing matches, at which there were seldom fewer than seven teams as competitors for the various prizes.

The 1st result is from the mean force of each horse in six teams of two horses, each team upon lbs. light sandy soil ........................................ $=156$

The 2nd result is from seven teams of two horses, each team upon loamy ground, near Great Berkhamstead ............................................ $=154$

The 3rd result is from six teams of four horses, each team with old Hertfordshire ploughs............ $=127$

The 4th result is from seven teams of four horses, each team upon strong stony land (improved ploughs) $=167$

The 5th result is from seven teams of four horses, each team upon strong stony land (old Hertfordshire ploughs) .................................................... $=193$

The 6th result is from seven teams of two horses, each team upon light loam ............................ $=177$

The 7 th result is from five teams of two horses, each upon light sandy land ............................ $=170$

The 8th result is from seven teams of two horses, each team upon sandy land................................ $=160$

The mean force exerted by each horse from fifty-two teams, or 144 horses, $=163$ pounds each horse; and although the 
speed was not particularly entered, it could not be less than at the rate of $2 \frac{1}{2}$ miles per hour.

As these experiments were fairly made, and by horses of the common breed used by farmers, and upon ploughs from various counties, these numbers may be considered as a pretty accurate measure of the force actually exerted by horses at plough, and which they are able to do without injury for many weeks;-but it should be remembered, that if these horses had been put out of their usual walking pace, the result would have been very different. The mean power of the draught-horse, deduced from the above-mentioned experiments, exceeds the calculated power from the highest formula of Mr. Leslie. I am, Gentlemen,

Your obedient servant,

B. Bevan.

V. Narrative of an Excursion to the Summit of the Peak of Teneriffe on the 23rd and 24th of Felruary 1829. By Rober'T Edward Alison, Esq.*

H AVING frequently observed the rapid fall of the atmospheric temperature when ascending from the sea-coast of Teneriffe to an elevation of 1000 feet, and on the contrary. the very slow alteration at higher points, I was desirous of ascertaining the proportional decrement of heat in the upper regions.

The ascent to the top of the Peak of Teneriffe is considered by the natives of the island as impracticable in the winter season, on account of the snow and the supposed extreme cold; it is therefore seldom made before the month of June, when it is free from snow: but I was not able to wait for a more genial season, as I was in daily expectation of returning to England; I therefore resolved to make the attempt.

On the 23rd of February, at 4 A.M., I left the Augustine convent Orotuca, which is situated nearly 1100 feet above the level of the sea. At the time of my departure the thermometer stood at $56^{\circ} \cdot 5$, and there was a gentle breeze from the N.N.W.

After joining a stout active young peasant who was to act as my guide, we entered the "Camino de C'rasna," which is dignified by the name of a road, although, like almost all the highways in the island, it is only a steep and uneven line of

- Communicated by the Author. 